\title{
Infinite Capital Accumulation Through the Endless Harvesting of Limitless Dead Souls: Criminogenic Asymmetries, Structural Inequalities, Mimesis, and Parallel Oligarchies
}

Eric Wilson

\begin{abstract}
This article is neither an empirical nor an analytical study; rather, it is a concise statement of a research paradigm that reflects the personal (and perhaps idiosyncratic) concerns of its author, which he wishes to continue and elaborate upon in much further detail at some point in the near future (if any). The general concern is with devising a functional criminological taxonomy of the multitudinous mutabilities migrating between neo-liberal political economy and organised and semi-organised criminality, here defined as criminogenic asymmetries. My central premise is this: although frequently associated in the scholarly literature with corruption, underdevelopment, anomie, and the breakdown of the brokerage of trust, neo-liberalism itself is the sufficient explanation for criminogenic asymmetries. As should be expected, the "moral panic" over the "death of democracy", already part of our post-1989 history but currently symbolised by the "power crime" presidency of Donald J. Trump, will be utilised as the primary empirical example of these trends, both concurrent and convergent.

Keywords: post-capitalism; post-Marxism; mimesis; velocity; crime; criminology; post-Soviet; Media; accumulation; oligarchy; asymmetries; political symbolism; scapegoat; spectacle; simulacrum; power; death

For citation: Wilson Eric. Infinite Capital Accumulation Through the Endless Harvesting of Limitless Dead Souls. Criminogenic Asymmetries, Structural Inequalities, Mimesis, and Parallel Oligarchies. Review of Business and Economics Studies. 2021;9(4):60-76. doi: 10.26794/2308-944X-2021-9-4-60-76

ОРИГИНАЛЬНАЯ СТАТЬЯ

\section{Бесконечное накопление капитала} посредством бесконечной жатвы бессчетных мертвых душ. Криминогенные асимметрии, структурные неравенства, мимезис и параллельные олигархии
\end{abstract}

Эрик Уилсон

\begin{abstract}
АННОТАЦИЯ
Предметом статьи являются пограничные вопросы экономической политологии и политической экономии. С методологической точки зрения эта статья не является ни эмпирическим, ни аналитическим исследованием. Основное внимание уделяется разработке функциональной криминологической таксономии многочисленных мутаций, мигрирующих между неолиберальной политической экономией и организованной или полуорганизованной преступностью, которые здесь определяются как криминогенные асимметрии. Центральный посыл статьи таков: хотя в научной литературе неолиберализм часто ассоциируется с коррупцией, отсталостью, аномией и разрушением доверительного управления, неолиберализм уже по своей природе является достаточным объяснением кримино-
\end{abstract}

(c) Eric Wilson, 2021 
генной асимметрии. Автор сделал вывод, что, как и следовало ожидать, «моральная паника» по поводу «смерти демократии» после 1989 г., символизируемая «преступлением властью» во время президентства Д. Трампа, будет и впредь приводиться в качестве основного эмпирического примера этих тенденций.

Ключевые слова: посткапитализм; постмарксизм; мимесис; скорость; преступление; криминология; постсоветский; СМИ; накопление; олигархия; асимметрии; политическая символика; козел отпущения; зрелище; симулякр; власть; смерть

\begin{abstract}
Для цитирования: Уилсон Эрик. Бесконечное накопление капитала посредством бесконечной жатвы бессчетных мертвых душ. Криминогенные асимметрии, структурные неравенства, мимезис и параллельные олигархии. Review of Business and Economics Studies. 2021;9(4):60-76. doi: 10.26794/2308-944X-2021-94-60-76
\end{abstract}

\begin{abstract}
"Liberalism and democracy, although compatible are not the same ... it is at least possible in principle that a democratic government may be totalitarian and that an authoritarian government may act on liberal principles [...] It would be impossible to assert that a free society will always and necessarily develop values of which we would approve, or even [...] that it will maintain values which are compatible with the preservation of freedom."-
\end{abstract}

Friedrich von Hayek

Paraphrasing Heidegger, the political destiny of the peoples of the West will be some variant of neo-authoritarianism, either elitist technocratic neo-liberalism or rightist neo-populism, the former already effectively realised with the latter (the minoritarian) drawing dialectical sustenance from the former (the majoritarian). At the risk of instantaneous obsolescence, I would suggest that the harbingers of the end of orthodox political representation are none other than what, with perfect hindsight, we can identify as the "the four spectres haunting Marxism," to wit:

(i) Capitalism's successful achieving of Infinite Accumulation ("capitalism sans reserve") 1

(ii) The unlimited penetration of all forms of political and social organisation by neo-liberalism rendering the universalisation of neo-liberalism

\footnotetext{
${ }^{1}$ 1. See Mehlman, (1977, p. 28). "Capital, in particular finance capital, having reached its maximal capacity for velocity, circulation, and flight, is now more than just dictating its own temporal regime. It now seeks to reproduce itself on its own, in an infinite series of structurally insolvent debts" (Mbembe, 2019, p. 111). See also Milanovic (2019 pp. 147-155) for global value chains; the embedding of entire segments and infrastructures of production segments throughout the peripheries is "probably the most important organizational innovation in this era of globalization" (lbidem, p. 147).
}

as global political culture a fait accompli (or socialism as false consciousness) ${ }^{2}$

(iii) The realisation of the bourgeoisie as the truly international class (Milanovic, 2019, pp. $136-147,211,214)$

(iv) The lumpen-proletariat as the true agent of "revolution," if not in their classic then certainly in their contemporary post-modern form as hyper-consumerist digitalised "pigs". ${ }^{3}$ ${ }^{2}$ Milanovic (2019), Chapter Five, for socialism as "false con-
sciousness". A process further accelerated through reality aug-
mentation that doubles both as a means of controlling per-
ception as well as providing a "virtually" endless frontier of
capital re-investment: "I have always argued that a simulated
reality will change and end up substituting itself for itself to
become a different reality. It will integrate its [own] simula-
tion. We end up having causal chains of successive realities. We
now live in the time of substitution and repulsion"-this as the
antidote for Jean Baudrillard's timelessness of seduction, the
repudiation of each successive virtual world as a reborn world-
economy to be (re-) colonized. We do not merely eternally al-
ter the "real" into new global markets (green industries; na-
notechnologies; cybernetic bodies; androgynous sex-regimes);
we sacrifice the actual to the virtual for the eternal rebirth of
capitalist replenishment (e.g., cyclical planetary engineering
and the Anthropocene) (Virilio \& Richard, 2012 , p. 70). Even
better - all of this can be translated into data which guaran-
tees unlimited future markets through high-velocity future
trading; "As long as surveillance capitalism and its behavioural
futures markets are allowed to thrive, ownership of the new
means of behavioural modification eclipses ownership of the
means of production as the fountainhead of capitalist wealth
and power in the twenty-first century" (Zuboff, 2019, pp. 56 ,
203; $87-92$, 11).

${ }^{3} 4$. For a full-throttle moral(-zing) screed on the porcine postmodern consumer as the true inheritors of the Earth, see Chatelet (2014). The great merit of Chatelet's work is that he shows the clear mutability between the central concepts of postmodernism with those of neo-liberalism; "One might speak of a Triple Alliance, political, economic, and cybernetic, capable of 'self-organizing' the explosive potentials of great human masses and of conjugating the benefits of the three prototypes of post-modernity"-homo economicus, (psychologism; rational choice theory) the "average man' (statistical reification), and homo communicans (mimetic, performative) (Ibidem, pp. $71-72 ; 22-24,166-171$ ). The net result of the universaliza- 
To simplify: the (now post-) Marxist nightmare is nothing other than infinite accumulation itself, for it enables capitalism to avoid its pre-determined world-historical execution at the hands of the deadly twins of the dialectic and the crisis of profit. It, in turn, leads directly to the equally hellish Trotskyite nightmare: the (hyperfinancialised) neo-bourgeoisie as the objectively globalist class ("globalist" in both its identity and its interests), which yields the "inevitabilism" of unlimited de-territorialisation and an equivalently unbounded cultural and political neutrality, culminating in the evacuation of the parochial, or "post-everything". Absolutely nothing here is accidental: only after it is far too late do we finally understand that allegedly "modern" capitalism is, and always has been, the re-capitulation of the "atavism" of primitive accumulation, the true fleshy horror at the heart of the capitalist worldeconomy, the latter serving as nothing more than as the staging ground for the re-capitulation of original accumulation throughout the saeculum. ${ }^{4}$ Through the mole-like "cunning" not of discontinuity but an occluded and occluding continuity does it come to pass that primitive accumulation attains the pseudo-transcendental status of the world-historical - original accumulation is History's true eternally revolutionary force, culminating in the (dead) world-spirit's final turn of the infernal screw: the death of the human is the world-necessity of the continuation of neoliberalism by other means.

With all of this in mind, it becomes fairly simple to understand structural inequality as a systemic property of neo-liberal globalisation (or "globalised political economy"). For simplicity I accept David Held's definition of this nebulous term, which equates speed with velocity and identifies both as cardinal features of neo-liberal political economy, a "process (or set of processes) which embodies a transformation in the spatial organisation of social relations and transactions - as-

tion of post-proletarian "Man", the tree and the fruit of the unified complex of post-modernism and neo-liberalism, is the following maxim: "capital is no longer a factor of production, it is production that is a mere factor of capital." Which doesn't mean that it isn't true, its neo-liberal pedigree notwithstanding (Ibidem, p. 81).

${ }^{4}$ For more on this admittedly sweeping statement, see Wilson (2008). The final word on this subject belongs to Hannah Arendt: colonialism is not the highest stage of capitalism; rather, capitalism is the preliminary stage of colonialism. sessed in terms of their extensity, intensity, velocity and impact - generating transcontinental or interregional flows and networks of activity, interaction, and the exercise of power" (Held et al., 1999, p. 16) Velocity is the "growing extensity and intensity of global interconnectedness may also imply a speeding up of global interactions and processes as the development of worldwide systems of transport and communication increase the potential velocity of the global diffusion of ideas, goods, information, capital and people" (Held et al., 1999Ibid, p. 15), which directly correlates with globalisation theory's notion of the critical variable of "real time communication", defined by Held as "the manner in which globalisation appears to shrink geographical time and distance; in a world of instantaneous communication, distance and time no longer seem to be a major constraint on patterns of social organisation or interaction" (Held et al., p. 15, fn 2. Emphases added). In Mckenzie Wark's own account, the "vector" of high-speed finance capitalism "responded enthusiastically to immaterial [information] technology, making one suspect a close affinity between the abstract social force that is money and the principles of the new technologies. [...] Now, the vector and capital are complicit in this, but the vector and capital are not identical. Capital drives the vector further and harder, forcing its technologies to innovate, but at the same time, it tries to commodify the fruits of this development. The vector may have other properties, values that escape the restriction of its abstract potential to the commodity form [...] the vector and capital are not the same thing [...], and the vector is not always a functional tool for capital" (Wark, 1994, pp. 168, 171 and 222). Her last point is vital: the key notion is the mutual dependence between acceleration and interdependence, which brings with it a system-wide shift consistent with the foundational presence of accumulation, both primitive and infinite, towards (or backwards) circulationism. Confounding socialism yet again, Jean Baudrillard was the first to see this: a circulationism of both economic and social capital magnified ten-thousandfold via the absolute and claustrophobic ubiquity of social media, "gifting" us an emancipation-as-subsumption into the jouissance of eternal spectacle. An exchange may be finite, but circulation is infinite; hence global capitalism as an equally immortal primitive accumulation with human capital itself - the 
digitally incorporated neo-liberal subject itself, as a bleeding frontier of a potentially unlimited source of surplus-value.

Capitalism [...] needs an opposition to save it from itself. By confronting and absorbing challenges, from worker's insurance to the welfare state, capitalism secures the social conditions that allow it to persist. [...] an essential aspect of the project of neoliberalism was determining how to pre-empt the opposition by building an extra-economic framework that would secure the continued existence of capitalism. Rather than a self-regulating market and an economy that eats everything [including itself], the neo-liberals envisaged and fought for an ongoing settlement between imperium and dominium while pushing policies to deepen the power of competition to shape and direct human life [now human capital]. The normative neoliberal world is not a borderless market without states, but a doubled world kept safe from mass demands for social justice and redistributive equality by the guardians of the economic constitution (Slobodian, 2018, p. 16).

Achilles Mbembe clearly senses the banality of Truth within all of this: "Capital, in particular finance capital, having reached its maximal capacity for velocity, circulation, and flight, is now more than just dictating its own temporal regime. It now seeks to reproduce itself on its own, in an infinite series of structurally insolvent debts" (Mbembe, 2019), p. 111). Of true profundity is that the very foundations of contemporary global governance enable the neo-liberal world-economy to circumvent Paul Virilio's “wall of History” through securing the eternal presence of the retreating horizon of screaming meat, ${ }^{5}$ the ever-deepening macro-colonising of the nation-states and the equally open-ended micro-colonisation of the interior of the Self (neo-liberal neo-subjectivity). The capitalist world-economy has been irrevocably transformed into the neo-liberal capitalist worldeconomy, rendering all four of the post-Marxist spectres immune to exorcism; "History equals: a series of signs and commodities that represent the personal agendas of people who fail utterly to rise to the occasion" (Walker, 2002, p. 197). The paradox of post-democratic politics is that, in Aristotelian terms, it combines the form of post-modernity (simulation, simulacra, virtual

\footnotetext{
${ }^{5}$ Apologies to Alan Moore.
}

reality, the digital) with the substance of premodernity (charism, gossip, rumour, conspiracy, familialism, tribalism, fashion, sectarianism, factionalism, patronage, network, de-centralisation, de-territorialisation, the nomadic, the liminal). If the lumpen-proletarians and their episodic "tactical" allies the petit-bourgeoisie are the true vanguards of authentically revolutionary politics (i.e., "extremism"), then the true Technik-Politik of the $20^{\text {th }}$ century is Fascism and not, as is erotically yearned for, the post-Bolshevik Marxism that has by now been thoroughly subsumed by the cultural logic of neo-liberalism as a political "system". This inescapable destiny drives Wendy Brown to the verge of self-harm.

Thus, again, does political rationality born initially in opposition to fascism turn out to mirror certain aspects of it, albeit through powers that are faceless and invisible-handed and absent an authoritarian state. It is not to say that neoliberalism is fascism or that we live in fascist times. It is only to note convergences between elements of twentieth-century fascism and inadvertent effects of neoliberal rationality today. These convergences appear in the valorisation of a national economic project and sacrifice for a greater good into which all are integrated, but from which most must not expect personal benefit. They appear as well in the growing devaluation of politics, publics, intellectuals, educated citizenship, and all collective purposes apart from economy and security (Brown, 2015, p. 219).

The wholescale conversion of the capitalist world-economy to neo-liberalism (=accelerationism + circulationism) carries within it two pathogens of elemental criminological import. The first is the globalisation of power crime; the second is the systemic entrenchment of neo-authoritarian forms of government. Both are the bitter fruits of the reification of primitive accumulation as velocity. For "power crime", I use the definition provided by Nikos Passas (2007, generally): fraud and corruption by elites that have substantial governmental power or economic power (typically as CEOs). Often, of course, they have both forms of power simultaneously. Elite criminals [or "control frauds"] have a far greater ability than non-elites to act dynamically to optimise the environment for fraud while "neutralising" their crimes psychologically and obtaining substantial impunity (Passas, 2007, p. 2). 
Passas identifies two "levels of dynamism" integral to power crime that are of particular interest to me. The first is spatial, "that elites are able to choose to operate wherever the legal, political, economic and cultural environment is most criminogenic and the payoffs to abuse the greatest." The second is causal, "that elites are able to change the environment [and...] make it far more criminogenic" (Ibidem). If we read this definition through the critical "lenses" provided us by Paul Virilio (Wilson, 2009), we realise that the criminogenic variable that connects space with causality is speed-politics: the relationship between power and speed, therefore, is of considerable criminological importance. While Passas' account does not explicitly refer to either velocity or neo-liberalism, his understanding of power crime is highly conducive to the narrative that I am constructing here because the essence of power crime is the control over definitions, perceptions, and appearances: "elite criminals" are best understood as those who undertake the criminogenic manipulation of the sign-systems that serve as the orthodox demarcations of "Law" and "Crime". The account provided by Vincenzo Ruggiero and Michael Welch is highly illustrative.

Perpetrators of power crime are offenders who possess an exorbitantly exceeding amount of material and symbolic resources when compared to those possessed by their victims. [...] We can argue with respect to power crimes that criminal designations are controversial and highly problematic due to perpetrators' higher degree of freedom. The capacity to control the effects of their actions allows those who have more freedom to conceal (or 'negotiate') the criminal nature of their actions. Suppose we translate the notion of freedom into that of resources. In that case, we can argue that those possessing a larger quantity and variety of them also have greater possibilities of attributing criminal definitions to others and repelling those that others attribute to them. They also have a greater ability to control the effects of their criminal activity and usually do not allow this to appear and be designated as such (Ruggiero \& Welch, 2009, p. 298).

The author's account of the manipulation of "symbolic resources" as a means of effecting the perceptual "disappearance" of criminal substance is highly suggestive of a simulated event, or spec- tacle. ${ }^{6}$ Although certainly not reducible to the visual, any critical understanding of power crime would benefit tremendously from careful consideration of the optical dimensions of the phenomenon. "Normal" crime, because it is a "low-velocity" phenomenon, is highly susceptible to detection and enforcement: "Normally, thieves face a fairly symmetrical environment: to steal more they have to take greater risks of detection, prosecution and sanction" (Passas, 2007, "Corruption”, p. 2). By contrast, power crime, precisely because it is a "high-velocity" phenomenon operating on the level of perception - that is, simulation - is able to effectively "disappear" into a total criminogenic environment of its own making. Accordingly, "elite criminals" are the very ones able to create an "environment in which engaging in massive fraud and corruption increases one's political power and status and greatly reduces the risks of detection and prosecution. Elite criminals optimise by creating fraud networks that help them maximise this asymmetry of risk and reward" (Passas, 2007, p. 2). Speed itself facilitates the transformation of the residuum of the "real" of a wholly "virtual" form of reality that supersedes all "common sense" notions of legality and political accountability, so that criminal sovereigns "are able to steal vastly more than non-elites, yet face less risk of detection, prosecution and sanction than do common non-elite thieves" (Passas, 2007, p. 13).

Of no lesser importance is that his definition presupposes an already entrenched and highly inequitable, hierarchical division of social and technological power, particularly with regards to

\footnotetext{
${ }^{6}$ It is also highly suggestive of "conspiracy theory," the bane of all attempts by radical criminology to theorize power crime and criminal elites, both of which invariably invoke the canards of "the cabal" or the "shadow government." The bottom-line is that power crime does not require a corresponding theory of conspiracy but it does presume to comprehensively describe a milieu that can serve as the necessary, if not sufficient, condition for the conspiratorial. "Critics of a power elite theory often call it 'conspiratorial', which is the academic equivalent of ending a discussion by yelling Communist. It is difficult to lay this charge to rest once and for all because these critics really mean something much broader than the dictionary definition of conspiracy. All right, then, if 'conspiracy' means that those men [of the alleged power elite] are aware of their interests, know each other personally, meet together privately and off the record, and try to hammer out a consensus on how to anticipate or react to events and issues, then there is some conspiring that goes on in CFR, not to mention in the Committee for Economic Development, the Business Council, the National Security Council, and the Central Intelligence Agency" (Dornhoff, 1969, p. 34).
} 
media. Again, Passas provides us with another useful tool for application: criminogenic asymmetries.

Criminogenic asymmetries are structural disjunctions, mismatches, and inequalities in the sphere of politics, culture, the economy, and the law. Asymmetries are criminogenic in that they [...] create opportunities for illicit profit; produce or strengthen the demand for illegal goods and services; generate incentives for particular actors to participate in illegal transactions; and reduce the ability of authorities to control illegal activities (Passas, 2007, "Corruption", p. 47; see also Passas, 2000, pp. 17, 19-20, 23 and 20-26).

There is nothing inherently "criminal" about authoritarian government; what is exceptional about it is its uncanny elective affinity with that structural inequality that doubles as the foundation of criminogenic asymmetries.

Citizenship in its thinnest mode is mere membership. Anything slightly more robust inevitably links with patriotism, love of patria, whether the object of attachment is a city, country, team, firm, or cosmos. In all cases, however, its consummate sign is the willingness to risk life [self-sacrifice], which is why soldiers in battle remain its enduring icon [...]. Today, as economic metrics have saturated the state and the national purpose, the neoliberal citizen need not stoically risk death on the battlefield, only bear up uncomplainingly in the face of unemployment, underemployment, or employment unto death [...] This citizen releases state, law, and economy from responsibility for and responsiveness to its own condition and predicaments and is ready when called to sacrifice to the cause of economic growth, competitive positioning and fiscal constraints (Passas, 2007, p. 218 and 219).

Idealism, profane or otherwise, forms no part of any of this: the decomposition of any viable form of social cohesion is the offal of neoliberalism's eternal quest for the immanent "instantification" of a wholly friction-less isotropic world of unmediated exchange. Seminal is the potentially infinite profitability of the "extractive" mechanisms of what Shoshana Zuboff has labelled surveillance capitalism, in which the intergenerational technological endo-colonisation of neo-liberal subjectivities offers up the prospect of a literally endless frontier of primitive accumulation: "Data extraction and analysis [...] is what everyone is talking about when they talk about big data. [...] The extraction architecture is combined with a new execution architecture, through which hidden economic objectives are imposed upon the vast and varied field of behaviour. [...] This undertaking aims not to impose behavioural norms, such as conformity or obedience, but rather to produce behaviour that reliably, definitively, and certainly leads to desired commercial results. [...] surveillance capitalists make the future for the sake of predicting it"-which adds a metahistorical dimension to the concept of futures markets trading: "As long as surveillance capitalism and its behavioural futures markets are allowed to thrive, ownership of the new means of behavioural modification eclipses ownership of the means of production as the fountainhead of capitalist wealth and power in the twenty-first century" (Zuboff, 2019, pp. 56, 203; 87-92, 11). Central to this project is the fleshy equivalent of global value chains: "behavioural surplus supply chains", the borderland of the truly infinite frontier of "instrumentarianism,", best understood as "the instrumentation and instrumentalisation of behaviour for the purposes of modification, prediction, monetisation, and control" (Zuboff, 2019, p. 351 and 352).

When we think about it rationally, we realise immediately that the cancellation (or aufgehoben) of liberal Democracy is neither "the end of history" nor "the end of politics"; it is, rather, the re-valorisation of an "elemental" politics, one, however, that is uniquely vulnerable to authoritarian machinations. In a word, post-democracy is nothing other than the Friend/Enemy distinction of Carl Schmitt (Schmitt, 1996), the prophet of the secularised state-of-exception: no longer national unities but virtual tribes governed by the electronic semiotics of contending integrated communities. If political representation is no longer possible, what could the polity be other than an arena of perpetual ritualistic combat? The catch, of course, is that Schmitt never anticipated social media. As Mbembe reminds us, "enmity now constitutes the spirit of liberal democracies, and [...] hatred gives them the impression of experiencing a pure present, a pure politics, using means that are themselves pure" (Mbembe, 2019, p. 117)-this, in large part, due to the accelerationism of a by now truly globalised neoliberalism. "At its core, liberal democracy is not compatible with the inner logic of global finance capitalism", continues 
Mbembe (Ibidem) (although this should perhaps be amended to "democracy is incompatible with the inner logic of finance capitalism"; liberalism as neo-liberal technocracy is fully compatible with the universality of high velocity "free trade") which leads to the return of political atavism.

The clash between these two ideas and principles is likely to be the most significant event of the first half of a twenty-first-century political landscape, itself shaped less and less by the rule of reason and more and more by the general release of passions, emotions, and affect. [...] Whether human civilisation can give rise to any form of political life at all is the problem of the twentyfirst century (Mbembe, 2019, p. 111 and 116).

The state of exception/moment of decision is necessarily a sacrificial act, the establishment of the identity of the one who is to be killed (whether physically or "merely" symbolically) in order to achieve the restoration of community harmony and social consensus so that "normal" politics can continue. Conversely, if "true" politics is an existential "intensity" 7 inseparable from warfare - that all "serious" political activity, always in opposition to that of the "normal" mundane, is identical with enmity - then the enemy must, out of necessity, take on, or be invested with the attributes of the scapegoat, the sacred enemy whose longed-for annihilation is the parousia of unifying conflictual mimesis that induces all of the parties to the conflict to settle upon a common rival, or enemy, whom they all wish to "strike down".

Whether we care to admit it or not, through both Schmitt and Rene Girard, we can no longer refuse to acknowledge the centrality of scapegoating, affectivity, and mimesis to the sausagemaking of politics. Less appreciated is an equivalent centrality of mimesis and imitative rivalry to the realm of international politics, territory pioneered by Hans J. Morgenthau himself, who defined power as a "ssychogenic condition which rested on inter-subjective relations [...]' power was for Morgenthau generally created through the interaction of people: as a result and quality of human action" (Troy, 2021, p. 6. Emphases added) The irreducible affectivity of the political, and of the mimetic nature of political affectivity, enables mimetic theory to point "International Relations

7 "Politics is a degree of intensity". Mike Grimshaw, "Introduction" in Taubes (2013, p. xxxvi). toward the need for a relational ontology of human desire and political order" (Troy, 2021, p. 17). The equation is simplicity itself: power $=$ social recognition $/ /$ power $=$ love $=$ desire $/ /$ social recog nition $=$ power/desire/love. "Power and love are intimately connected, the desire for one growing out of the fulfilled or frustrated desire for the other, one state shading imperceptibly into the other; and the longing for immortality. For the perpetuation of one's existence beyond its natural limits, intermingles with the desire for power and love." 8 More concretely, power as prestige constitutes the supreme mimetic object of international politics, at least in its classical Realist form; the "lust for power" is inter-relational, which, for Morgenthau, means that "the political in the specific sense consists on the particular degree of intensity of the connection created by the state's will to power between its objects and the state." Politics is "never an either/or state of affairs, but always a matter of degree, necessarily depending on how intense - and potentially violent - a conflict had become." 9

The other root of conflict and concomitant evil [in addition to the egoism of the State actor] stems from the animus dominandi, the desire for power. This lust for power manifests itself as the desire to maintain the range of one's own person with regard to others, to increase it, or to demonstrate it. In whatever disguises it may appear, its ultimate essence and aim are one of these particular references of one person to another. Centred as it is upon the person of the actor in relation to others, the desire for power is closely related to the selfishness of which we have spoken but is not identical with it. ${ }^{10}$

Which leads us directly to our next major problem: power and the crisis of un-differentiation, or how can any particular State retain its sense of uniqueness (or singularity) within an accelerationist global political economy of complex interdependence? To put it another way: how does a State that lacks prestige resolve the ontopolitical crisis inflicted upon it through its "love" of the model - the State that is the holder of prestige that all other States naturally gravitate towards through the desire for social recognition,

\footnotetext{
${ }^{8}$ Hans J. Morgenthau in Troy (2021, p. 25).

${ }^{9}$ Hans J. Morgenthau and William E. Scheuerman in Troy (2021, pp. 22-23).

${ }^{10}$ Hans J. Morgenthau in Troy (2021, pp. 24-25).
} 
the psychic (or propagandistic) fuel of mimesis? According to Pierre Bourdieu: "Social identity lies in difference, and difference is asserted against what is closest, which represents the greatest threat" ${ }^{11}$; not a game of "zero-sum" but an "erotically" driven strategy of structural positioning.

For the claim to universality which inspires the moral code of one particular group is incompatible with the identical claim of another group; the world has room for only one, and the other must yield or be destroyed. Thus, carrying their idols before them, the nationalistic masses of our time meet in the international arena, each group convinced that it executes the mandate of history, that it does for humanity what it seems to do for itself, and that it fulfils a sacred mission ordained by providence, however, defined. Little do they know that they meet under an empty sky from which the gods have departed. ${ }^{12}$

The internal political logic of this integrated world system is governed through the mechanism of hegemony, which may best be understood in terms of a kind of "socialisation" process among States, a variant of Norbert Elias' civilising process undergone by international legal personalities. Intriguingly, civilising socialisation ordinarily takes place as a systemic response to prolonged global dysfunction.

[Socialisation] occurs after wars and political crises, periods marked by international turmoil and restructuring as well as fragmentation of ruling coalitions and legitimacy crises at the domestic level. The simultaneity of international and domestic instability creates the conditions conducive to socialisation. At the international level, the emerging hegemon articulates a set of normative principles in order to facilitate the construction of an order conducive to its interests. At the domestic level, crisis creates an environment in which elites seek alternatives to existing norms that have been discredited by events and in which new norms offer opportunities for political gains and coalitional realignment. (Ikenberry \&Kupchan, 1990, p. 284. Emphases added).

The co-linkage between the World-System and global neoliberalism demands the creation of an international system that is both anti-world empire and committed to free trade; "the emergence

\footnotetext{
11 Pierre Bourdieu in Troy (2021, p. 64).

${ }^{12}$ Hans J. Morgenthau in Troy (2021, p. 64).
}

of a [capitalist] world market was dependent on the pluralistic structure of the European (and, subsequently, the global political system)" (Gilpin, 1981, p. 131). The crucial point is that hegemony is not identical with world-empire, which presupposes territorial conquest, military force, and forcible political and legal unification: a universal state (Rome, China, Russia). Hegemony, rather, is based upon expressly pluralistic principles, reflected through the alternating geo-political strategies of "domination" and "influence," the latter, because of its predominantly non-military nature, the more "cost-efficient" of the two strategies. As Wilhelm Grewe points out:

In sum, an international legal order can only be assumed to exist if there is a plurality of relatively independent (although not necessarily equal-ranking) bodies politic which are linked to each other in political, economic and cultural relationships and which are not subject to a superimposed authority having comprehensive law-making jurisdiction and executive competence. In their mutual relations, these bodies politic must observe norms which are deemed to be binding on the basis of a legal consciousness rooted in religious, cultural and other common values. (Grewe, 2000, p. 7. Emphases added).

This complex interplay between material and ideological factors parallels a concomitant rivalry among contending conceptions of the international legal order. "This order emerges in every age as a result of the struggle of the legal and political ideas and positions of the rival powers of that age, in which the leading power succeeds in making its ideas and positions prevail and in securing recognition of their natural effectiveness." ${ }^{13}$ The problem for western States has always been the occidental historical legacy of "Great Power Politics" that reached its apotheosis in the $18^{\text {th }}$ century.

The political and international legal programmes of the modern European States were

\footnotetext{
${ }^{13}$ Grewe (2000, p. 275). For Grewe the normative (and normalizing) alignment or convergence of international actors, on both the state and sub-state level, acts as the sufficient cause of what we would consider to be an international society governed by the "rule of law". "The totality of diverse legal rules deserves to be called a legal order if it deals with the totality of facts needing to be regulated legally in a manner which corresponds to the specific intellectual, cultural, social and political situation in question and which establishes directions for existing in this situation. In other words, the principal context in which individual legal rules and institutions are found is not logical, but morphological" (Ibidem, p. 32, Emphases added).
} 
all [...] expressions of ideologies of national expansion. The stronger the leading position of the particular predominant power, the more that State marked the spiritual vision of the age, the more its ideas and concepts prevailed, the more it conferred general and absolute validity on expressions of its nationalist, expansionist ideology (Grewe, 2000, p. 23).

But, as Morgenthau intuited, it is all just a question of social recognition, one between States at least as much as between people(s). In sharp distinction to pure Machtpolitik, the conceptualisation of hegemony as cultural influence, or soft power, renders its practical operation inextricable from the wider networks of legal legitimacy.

Hegemony is [...] something more and different than dominance pure and simple: it is the additional power that accrues to a dominant group by virtue of its capacity to lead society in a direction that not only serves the dominant group's interests but is also perceived by subordinate groups as serving a more general interest. [...] If subordinate groups have confidence in their rulers, systems of domination can be governed without resorting to force. But if confidence wavers, they cannot [...] When such credibility is lacking, we shall speak of 'dominance without hegemony' (Arrighi \& Silver, 1999, pp. 26-27).

The "true" hegemon is the single State capable of effectively policing international public order through its effective performance as an anti-imperialistic (i.e., dominating) actor.

The analytical tool devised by Immanuel Wallerstein to identify the model-State, or hegemon, within a particular world-system at any given moment in time was the concept of geo-culture, a term which quite beautifully encapsulates the potential of Elias' civilising process to international politics. This notion of the hegemon-as-regulatorof-geo-culture (or the bearer of "soft power") as the-universal-model-for-social-recognition renders hegemony's practical operation inextricable from wider problems of its international legal legitimacy. Here is where geo-culture is actively (re-) deployed as a hopefully non-violent means of international coercion: the hegemon as a model will not only act as the embodiment of the affective "ideal" for the particular historical moment in question (think of the France of Louis XIV in the $18^{\text {th }}$ century or Victorian England in the mid-19th), it will also, through the calculated pollination of its cultural influence, bring all of the imitating States towards the commonly agreed goals, which ordinarily means their political and economic objectives. The "true" hegemon is the single State capable of effectively policing international public order through its effective performance as an antiimperialistic actor (meaning anti-"zero-sum") that most effectively manages the world-economy on the basis of the mutuality of the greater economic interests of all actors within the system.

Any moment when a hegemonic power is omnipotent [it is] capable of doing anything it wants. Omnipotence does not exist within the interstate system [otherwise, the hegemon would constitute a world-empire]. Therefore, hegemony is not a state of being but rather one end of a fluid continuum that describes the rivalry relations of great powers to each other (Wallerstein, 1979, p. 89).

And in the $20^{\text {th }}$ century, this means the United States and global neo-liberalism.

Hegemony involves more than core states. It may be defined as a situation wherein the products of a given core state are produced so efficiently that they are by and large competitive even in the other core states, and therefore the given core state will be the primary beneficiary of a maximally free world-market (Wallerstein, 1980, p. 38).

The operational linkage (inter-relational) between hegemony and legitimacy, and the correlative inter-dependency between hegemony and global capitalism, dictates that the historically successful hegemons - the successive Protestant 'commercial republics' of the United Provinces (1648-1740), the United Kingdom (1815-1914) and the United States (1945-?)-be both the most successful practitioner and the most persuasive advocate of political Liberalism and free-market economics during its prescribed period of hegemonic influence.

Hegemonic powers during the period of their hegemony tended to be advocates of global "liberalism". They came forward as defenders of the principle of the free flow of the factors of production (goods, capital and labour) throughout the world-economy. They were hostile in general to the mercantilist restrictions on trade, including the existence of overseas colonies for the stronger countries. They extended this liberalism to a generalised endorsement of liberal parliamentary institutions (and a concurrent distaste for political 
change by violent means), political restraints on the arbitrariness of bureaucratic power, and civil liberties (and a concurrent open door for political exiles) (Wallerstein, 1979, p. 41).

And it is precisely at this juncture that neoliberalism's lethal threat to democracy manifests clearly. As the most successful (capitalistic) State, the hegemon will also serve as the model for the properly constituted international actor, leading all other States to behave as emulators (with varying degrees of success). But the capitalist worldeconomy is no longer (if it ever was) a classical one, but a neo-liberal one. Therefore, the mimetic nature of geo-culture, the psychic component of the quixotic quest for international recognition, will cause States to emulate (meaning "to seize") that State which has successfully realised the neo-liberal ideal - which is an anti-democratic one. Therefore, today's bearer of geo-culture, the mantle of the model, will be that State which has the most completely harmonised neo-liberal substance with post-democratic, or neo-authoritarian, form. And that means that the contest over hegemony can only be realistically assumed to be occurring between two States that are weirdly twinned, each having an extensive history of hegemonic ambition, one wholly successful, the other partial: The United States (a multi-ethnic post-colonial liberal continental frontier society post-democratic techno-elitist oligarchic republic) and the Russian Federation (a multi-ethnic postcolonial absolutist continental frontier society neo-authoritarian neo-populist oligarchy). Plus ça change, moins ça change.

The unambiguous emergence of the U.S. and Russia as mimetic doubles, both governed by oligarchic authoritarian capitalism (the defining features of which I will describe shortly) constitutes a localised transformation within a wider process following 1989: the transition of the U.S.S.R. and Warsaw Pact states, along with the PRC, from prospective model to willing imitator within a now unipolar world-system. Heed the words of Ryszard Legutko, a Polish member of the European Parliament, who adopts a robustly mimetic approach in dissecting the unipolar "Age of Imitation" following the dissolution of the Warsaw Pact: among the now "leaderless" eastern European States, the "deeper wisdom was to copy and imitate (Legutko, 2016, pp. 11-13). The more we copied and imitated, the more we were glad of ourselves. Institutions, education, customs, law, media, language, almost everything became all of a sudden imperfect copies of the originals that were in the line of progress ahead" (Legutko, 2016, p. 41; see also Krastev \& Holmes, 2019, pp. 6-7). The downside of all of this was an interminable case of pathological ressentiment.

Under the contemporary conditions of colonisation, assimilation and colonisation are contradictory. [... the colonised] soon discovers that he would not be saved even if he agrees to everything. In order to be assimilated, it is not enough to leave one's group, but one must enter another; now, he meets with the coloniser's rejection. [...] He can never succeed in becoming identified with the coloniser, not even in copying his role correctly. [...] If [the coloniser is] rude, he will say that the colonised is an ape. The shrewder the ape, the better he imitates, and the more the coloniser becomes irritated (Memmi, 1991, p. 127 and 124).

In terms of Rene Girard's singular version of mimetic theory, what we are faced with here is a double mediation: the success of the model (the mediator of the "ideal" to the world at large) in thwarting the mimetic desire of the subjectemulator increases, not decreases, the mimic's existential intensity, so that "by persisting in his will to acquire the object, the disciple will become in turn a model/obstacle to his mediator" (Wilmes, 2019, p. 95; Brighi \& Cerella, 2015, p. $10)$. For Girard, each member of the mimetic dyad "becomes the imitator of his own imitator and the model of his own model. Each tries to push aside the obstacle that the author places in his path'” (Wilmes, 2019, p. 95)-which succinctly explains the apparent rise of the so-called "Far Right" in post-GFC eastern Europe; while it is debatable how much such ressentiment objectively alters the world-system outside of the geo-cultural, it is beyond doubt that the rhetoric of humiliation is central to the rightist radicalisation of the domestic politics of the copy-cat states.

When Central Europe's Populists rail against a perceived Imitation Imperative [i.e., "there is no other way"] as the most obviously insufferable feature of liberalism's hegemony after 1989, they obviously mean something less generic and more politically provocative. The form of comprehensive institutional imitation at issue involves; first, the acknowledged moral superiority of the imitated over their imitators; second, a political 
model that claims to have eliminated all viable alternatives; third, an expectation that the imitation will be unconditional rather than adapted to local traditions, and, fourth, a presumption that representatives of the imitated (and therefore implicitly superior) countries could legitimately claim a right to monitor and evaluate the progress of imitating countries on an ongoing basis (Krastev \& Holmes, 2019, p. 9).

And given the intensely mimetic nature of geoculture, coupled with the hyper-competitiveness of neo-liberal in its own right as a form of political economy, this outcome could not be otherwise. A failure of recognition - or permanent humiliation - structurally embedded within international politics spawns systemic ressentiment: every nation that becomes a "copy-cat" is unavoidably subject to mimetic rivalry because the imitator is "inevitably focused on the source of importation - an object of imitation by definition - and reacts to it. Because the model was superior to the imitator in the latter's own perception (its being a model implied that), and the contact more often than not served to emphasise the latter's inferiority, the reaction commonly assumed the form of ressentiment $" .{ }^{14}$ And it is specifically ressentiment, not merely vengeful rivalry or ultra-nationalist competitiveness, that is at issue because the loser's dilemma is both existential and normative.

The imitation of moral ideals, unlike the borrowing of technologies, makes you resemble the one you admire but simultaneously makes you look less like yourself at a time when your own uniqueness and keeping faith with your group are at the heart of your struggle for dignity and recognition. [...] This self-contradictory request to be both an original and a copy was bound to be psychologically stressful. A feeling of being treated disrespectfully was also fomented by what can be reasonably identified as the central irony of post-communist democracy-promotion in the context of European integration: the Central and East European countries ostensibly being democratised were compelled, in order to meet the conditions for EU membership to enact policies formulated by unelected bureaucrats from Brussels and international lending organisations. [...] Pretending to rule themselves while being ruled by Western policy-makers was bad enough. The last straw

${ }^{14}$ Leah Greenfeld at ibid., 219 fn. 22. was being disparaged by visiting Westerners who accused them of merely going through the motions of democracy when that was exactly what political elites in the region thought that they were being asked to do (Krastev \& Holmes, 2019, p. 9. Emphases added).

The even crueller paradox is that the imitator can never escape the shaming gaze of the model (or, in the case of the E.U., the "mediator" of the model, which is the United States-ashegemon) because, by definition, their mimicry will always remain the second rate, as far as the cannibalistic heirs of two world wars were concerned, anyway. ${ }^{15}$ Because copy-cat nations are legally authorised plagiarists, they must, on a regular basis, seek the blessings and approval of those who hold the copyright to the political and economical recipes being borrowed and applied second-hand. They must also unprotestingly accept the right of Westerners to evaluate ${ }^{16}$ their successes or failures at living up to Western standards (Mazower, 1998, p. 73).Which was how Greece became Atlantis.

The logic of reciprocity being what it is, a retaliatory re-action from the imitator was to be expected: an escalating intensification of imitation. The subject-of-desire emulates the object more successfully than does the model-mediator; the catch here is that for the former Communist states to "out-rival" either the E.U. or the U.S., they have to prove the true nature of the object (hegemony) is not liberal-democratic but illiberalauthoritarian - which, thanks to neoliberalism, is the "truth" of the model they seek to copy. Naturally, this is something supremely easy to do with the

\footnotetext{
${ }^{15}$ The irony of that motley collection of States who are the co-inventors of both Communism and Fascism really cannot be improved upon short of divine inspiration. Mark Mazower expresses it pithily. "The intellectual tradition which identifies Europe with the cause of liberty and freedom goes back many centuries. But if we face the fact that liberal democracy failed between the [world] wars, and if we admit that communism and fascism also formed part of the continent's political heritage, then it is hard to deny that what has shaped Europe in this century is not a gradual convergence of thought and feeling, but on the contrary a series of violent clashes between antagonistic New Orders. If we search for Europe not as a geographical expression, but as what Federico Chabod called 'an historic and moral individuality,' we find that for much of the century it did not exist." It still doesn't as proven by the E.U.'s impeccable credentials as the world's "purist" neo-liberal organization (Mazower, 1998, p. 27).

16 The dreaded "bench-mark" and "best practices" of neo-liberal corporate governance now applied to so-called "sovereignties".
} 
technocratic-managerial-elitist E.U., as Legutko explains with striking clarity.

The European Union was not deliberately created as anti-democratic system to countervail the weaknesses of democracy, but on the contrary, as a hyper-democratic or hyper-liberal-democratic project. At least since the time of Maastricht, it has been in the hands of politicians and bureaucrats who, whatever their party affiliation, consider themselves to be model liberal democrats ready to convert the whole of Europe and even the whole world to liberal democracy. Consequently, European politicians do not see any problem in singing the praises of liberal democracy while failing to tolerate any deviation from the orthodoxy of the mainstream. Believing themselves to be the embodiment, the quintessence, and the fundamental guarantee of the liberal-democratic order, they consider it obvious that all those who think differently and challenge their authority must be enemies of the order and that fighting them is just defence. [...] To the European politicians, the fact that the actual direction of EU policy is created by people who do not have an electoral mandate is of no particular importance, because - as they probably assume - these people were selected and anointed by the elite mainstream (Legutko, 2016, pp. 87-88).

Here's the joke: precisely because the E.U. is the single largest international organisation of exclusively copy-cat states, ${ }^{17}$ it comes as no surprise that it "reflects the order and spirit of liberal-democracy in its most degenerative version" (Legutko, 2016, p. 87). Just as with the Japanese - another formerly occupied people supremely adroit at imitation - the eastern Europeans as imitators perceive the truth of the model-mediator with transcendental insight. In order to resolve their crisis of social recognition within the international sphere, they must re-constitute themselves as the new model by becoming even more undemocratic (and corrupt) than the E.U. itself. What's more, they are ideally suited to exploit the reams of evidence provided by Europe explicating the multiple convergences of parallel oligarchies and reciprocal (and reciprocating) forms of power crime - the political manifestation of equally parallel eastern and western neoliberal criminogenic asymmetries as proof of the

\footnotetext{
${ }^{17}$ That is, copying These "United States".
}

"rivalry-in-debasement" linking the model with its mimic and allowing the latter to overcome the former. And if this is the true dynamic governing the mimetic-criminogenic-neo-liberal rivalry between the E.U. and ex-Soviet bloc states - mere "regional" hegemons at best - then how much more "existentially intense" must be the rivalry between the two (or three) legitimate contenders to global hegemony?

\section{The moral panic over Donald J. Trump}

According to Alain Badiou, the world unexpectedly came to an end on November 82016 .

Everybody [...] understands that the perpetuation of inequalities engendered by capitalism, and especially by the law of the concentration of capital, can hardly be a worthy destiny for human beings. Sartre used to say that, if the human species were capable of no more than that, if the human species were capable of no more than that, it would leave no better memory of itself than that left by ants. "Perhaps," replies the liberal, dominant today. "But it's the only real possibility: everything else is both worse and ultimately impossible. Look at Russia, look at China." The power of the liberal capitalist way lies in declaring itself to be the only way. It doesn't even need to declare itself to be the best way, since it has succeeded in convincing practically everybody that another way, a second way, doesn't exist. Ants we may be, perhaps, but better to be an ant than nothing. ${ }^{18}$

What accounts for such infantilised wailing and gnashing of teeth wholly unbecoming for an intellectual of Badiou's (presumed) calibre? On the one hand, it is a simple expression of a political phobia of the Left that has reached pathological intensity over the past decade steered by the alleged resurgence of populism. Which is ironic, really, as populism, in its classical form, evolved in the U.S. as a fairly radical form of "direct democracy". The deeper, and more plausible explanation for the obsession is the recent history of eastern Europe and of Russia itself that totally confounds the Left: that right-wing/nationalist populism has emerged as the most effective bulwark to globalisation, once again removing socialism from its self-proclaimed position as the vanguard of

${ }^{18}$ See Badiou (2019, p. 7). Funnily enough, speculative realist philosophers such as Quentin Meillassoux with whom Badiou has been linked, stake everything on the complete absence of metaphysical difference between the Human and the ant. 
History. Badiou's fellow traveller Ernesto Laclau is particularly lucid on this point.

By "populism" we do not understand a type of movement - identifiable with either a special social base or a particular ideological orientation but a political logic. All the attempts at finding what is idiosyncratic in populism in elements such as a peasant or small-ownership constituency, or resistance to economic modernisation, or manipulation by marginalised elites are [...] essentially flawed: they will always be overwhelmed by an avalanche of exceptions. What do we understand, however, by a "political logic"? [...] While social logics consist in rule-following, political logics are related to the institution of the social. ${ }^{19}$ Such an institution, however, is not an arbitrary fiat but proceeds out of social demands and is, in that sense, inherent to any process of social change. As we also know, this change takes place through the variable articulation of equivalence and difference, and the equivalential moment presupposes the constitution of a global political subject bringing together a plurality of social demands. This, in turn, involves [...] the construction of internal frontiers and the identification of an institutionalised "other" (Lacau, 2005, p. 117).

The real "cunning of History" at work here is that the evolutionary logic of capitalism itself provides the means for the infinite postponement of socialism: the formation of that "mass identity" which was supposed to herald the unstoppable rise of a universal proletariat has been effectively re-engineered by neo-liberalism to create impenetrable "blobs" of digital populations which are empowered to undertake authentic revolutionary transformation: the decomposition of socius into contending on-line consumers; "Entire peoples labour under the apprehension that the resources for continuing to assume their identities are spent. They maintain that an outside no longer exists such that to protect themselves against threats and dangers the enclosures must be multiplied" (Mbembe, 2019, p. 2). And this, in turn, feeds directly into the global revenge of the mimics, neopopulism and a hyper-protectionism as "a way of erstwhile imitators to avenge themselves on their would-be models by revealing the latter's unattractive defects and irksome hypocrisy" (Krastev \& Holmes, 2019, p. 15). A race to the top of the

\footnotetext{
${ }^{19}$ First order/Second order or foundational/non-foundational.
}

new neo-liberal order through the symmetrical race to the bottom of post-democracy. Because of their respective geo-political "weight" The-StatesThat-Used-To-Be-Known-As-Communist adopted local variations, or parodies, of mirroring: for the Warsaw Pact, it was unveiling the authoritarian truth of the E.U.; for Russia it was it unveiling the authoritarian truth the entirety of international public order; for the Chinese it was a re-doubling of an almost autistic form of cultural narcissism, unveiling its own authoritarian essence and then daring the world to challenge it (so far no one has). But the real news is that the U.S. itself responded in kind as the hegemon-model (given that this is a double mediation) but in an utterly bizarre way: it proved its unmediated relationship to the object-of-desire of a now illiberal neo-liberal hegemony by demonstrating its wholly nativist capacity for neo-authoritarianism.

It is within this competition of what we might call "counter-mirroring" that we need to understand the defining trope of Trump's presidency: "Making America Great Again" (MAGA) is superficially populist and ultra-nationalistic but, in truth, is neither; the emphasis is not on "Again" but "Great" meaning America as the true hegemon (Mark II) of a re-conceptualised world-system of neo-liberal realpolitik. "For Trump, normalisation means "the restoration of the US as a selfish state among selfish states." ${ }^{20}$ MAGA can be rightly understood as a contemporary example of the Machiavellian Moment, the recovery of the vitally necessary civic virtù that is indispensable for political success in an irreducibly anarchic and mimetic international system.

Trump's "charisma" [...] is largely based on is mould-breaking ways. And the most exceptional thing about his exceptional presidency is his rejection of the myth of American exceptionalism. He has accomplished something which would have been previously thought impossible. He has reconciled America's jingoistic citizens to the idea that America can be "great" without being an international leader, ${ }^{21}$ without being morally superior, without being especially innocent, and

\footnotetext{
${ }^{20}$ Janan Ganesh in Krastev and Holmes (2019, p. 146).

${ }^{21}$ That is, the avatar of a liberal hegemony grounded upon multilateralism, "humanitarianism" (including the supremely suspect practice of "humanitarian intervention"), and the approximately equitable distribution of outcomes for other members of the core-zone - the States who most mirror the U.S.
} 
without having any right to lecture other countries. He has detached America's congenial selflove from the idea that America is "special" in the sense of morally superior (Krastev and Holmes, 2019, p. 148).

American lefties simply cannot retain their bile. “Trump's battle cry is: 'We need somebody that can take the brand of the United States and make it great again'" (Krastev and Holmes, 2019, p. 146). Decisively repudiating the geo-culture of liberal internationalism by way of a radically new nativist-based demolition of the shibboleth of “American Exceptionalism," Trump's “"greatness' involves the obliteration of America's selfprofessed uniqueness and its assimilation to the rest of the mundane world" (Krastev and Holmes, 2019 , p. 148) so that for him "disclaiming American righteousness is a first step towards escaping the self-defeating do-gooder illusions induced by the myth of American exceptionalism" (Krastev and Holmes, 2019, p. 147). Therein lies the rub: Trump was $100 \%$ correct in his assumptions. "The politics of imitation has destroyed the sense that we live in a common reality but it has increased the fear that we are becoming much more alike that is, equally unprincipled and cynical - than we would ever before have believed (Krastev and Holmes, 2019, p. 136)." Which explains the total weaponisation of "electoral interference" as moral panic by the mass media. Again, the truth is counter-intuitive but, for that very fact alone, supremely cunning. Because everyone knows the global drift is towards neo-liberalism, everyone also knows that democracy, in its classic representational form, is defunct. Therefore, Trump is a priori guilty of every anti-democratic crime conceivable precisely because the U.S. is now imitating the freshly minted geo-culture of neoauthoritarian post-democracy in the most competitive manner that it can manage.

For those countries [...] who have never had the privilege of democracy and occupy a large part of the world, legitimacy entails primarily, if not exclusively, obeying the outcomes of elections. But suppose the West undermines election results in these countries, as happened in Algeria and Egypt. In that case, all its well-intentioned sermonizing in favour of democracy will be seen as a mockery and as confirmation of the old, widely held notion that it is wise to think twice before following what the West seeks to promote (Calasso, 2017, p. 30).
Once more, political mimesis operates with as much existential intensity within the domestic as it does in the international sphere.

Disillusioned with their own democracies, Westerners are now beginning to see their own political systems as not much more genuinely democratic than the Russian one. [...] Whether Russian interference in Western elections has had a significant influence on outcomes is debatable. But the West now shares Russia's post-Cold War fears of polarisation, ungovernability and disintegration. [...] the imitator-imitated relationship, as understood immediately after the communist collapse, seems to have been brutally reversed (Krastev \& Holmes, 2019, p. 133).

And now comes the cruellest turn of the blade for the self-hypnotised "woke" among us.

It is worth noting in this context that only the most left-wing members of the Democratic Party deny that "the US stands above other nations." This provides a good measure of Trump's hypnotic [sic] powers. He has charmed his nationalistic base into thinking exactly like the most liberal of self-doubting Democrats without obliging them to abandon their intolerant and xenophobic fantasies. $^{22}$

Expressed formulaically, the U.S. and the Russian Federation exist within a triangulated relationship, in which both are contesting possession of the new geo-cultural model of the neoauthoritarian hegemon. Trump's "transparent-ly evil" (re. Baudrillard) genius was to pioneer a way of thinking out loud the unthinkable and thereby rendering sayable the unspeakable while being rewarded with supreme power for precisely so doing. In terms of the substantive content of his policies, much of it was fully consistent with the orthodox center-Right. His breakthrough was his innovation of a new form of political speech, a normalised brutalism that, through the "shock and awe" of content and delivery (140 characters; Twitter), achieved full-spectrum dominance of all forms of political communication: the-politicsof-the-very-worst-as-pure-war realised with a vengeance by a crypto-grotesque-sublime hybrid

\footnotetext{
${ }^{22}$ See Krastev and Holmes (2019, p. 148. Emphases added). That the exact reverse might be true is, of course, never considered, said omission the precondition for a new game of mirrordoubles, this time within the national arena: if the U.S. really is a neo-authoritarian post-democratic neo-liberal capitalist state, then the Constitution serves as a stumbling-block (skandalon) for both sides equally.
} 
of Andrew Jackson, Louis Bonaparte, and William Randolph Hearst (the "real" model for the Wellesian re-engineered Wayang-esque protagonist of Trump's favourite film, Citizen Kane (Osborne and Roberts, 2017, p. Xv)).

Trump's surprisingly banal policies largely fit the mould of orthodox conservatism, in almost complete opposition to his civilite-shattering political spectacle. ${ }^{23}$ But for an utterly phantasmagorical version of this only apparent paradox, see Timothy Synder, The Road to Unfreedom: Russia, Europe, America (London: Bodley Head, 2018), wherein the (somehow) unstoppable Vladimir Putin manages (somehow) to "create" the (somehow) unbeatable Donald Trump, a liberal paranoid conspiracy rant of vastly entertaining proportions: "Russians raised 'a creature of their own' to the presidency of the United States. Trump was the payload of a cyberweapon, meant to create chaos and weakness, as in fact he has done" (Snyder, 2018, p. 219). But Snyder misses the real point, which, being true, is too painful: "The future arrived first in Russia," ${ }^{24}$ rendering everything that may have transpired between Russia (and/or the Ukraine) and Trump of secondary importance, anecdote not process. What is process are the national convergences driven by mirroring oligarchies: in perfect accordance with Thomas Piketty, in Russia, the top ten per cent owned 89 per cent of total household wealth in 2016; in the US, it was 76 per cent (Snyder, 2018, p. 258). In terms of political economy, the two oligarchies are virtually identical with regard to the structural inequalities they manage; in terms of discursive and governance apparatus, they differ slightly - ordo-liberal technocratic elitism for the U.S. ${ }^{25}$ right-wing nationalist populism for Russia, each with its respective opposite the default position of both. Criminogenic capitalism and criminal sovereignties are the sufficient causes of oligarchism. ${ }^{26}$ As Vladimir

\footnotetext{
${ }^{23}$ See Kruse and Zelizer (2019, pp. 349-358). For a concise account of Trump as disrupter of neo-liberal technocracy, see Babones (2018).

${ }^{24}$ I would change this to "Russia and eastern Europe".

${ }^{25}$ Which can be proven by this supremely elementary triangulation of American political economy: Big-Tech/Big-Data, Silicon Valley (or California), and the DNC.

${ }^{26}$ See Wilson (2012), and also Milanovic (2019, p. 251, fn 18): "both an index of a country's globalization and an index of a country's corruption are positively correlated with the number of billionaires." Milanovic makes the slightly counter-intuitive but not unpersuasive argument that corruption within the Soviet bloc states was fairly low because of the existence of capital controls, the difficulties of currency conversion, and the
}

Gusinsky, "the ultimate Russian oligarch" of mass media put it: " The oligarch was a special species which could only have been born in Russia in the late 1980s [...] We came out of the Soviet system, but we overcame that system and the remarkable criminality in the country. We were the people with fangs growing from our necks.'” Ostrovsky comments: "After seventy years of Soviet socialism, feudalism seemed like a step forward," the oligarchs taking to heart Silvio Berlusconi's admonition to his mimic Putin, "'What is not on TV does not exist'” (Ostrovsky, 2017, pp. 176, 174, 203-204 and 7). Under Putin, Russia "exported" nothing to the U.S.; instead, it re-exported. Even better the Russian people "became post-Soviet a breath before the whole world went post-everything," revealing that "the great drama of Russia is not the "transition' between communism and capitalism, between one fervently held set of beliefs and another, but that during the final decades of the USSR no one believed in communism and yet carried on living as if they did, and now they can only create a society of simulations" (Pomerantsev, 2014, p. 213 and 199). As we now do in the West. For there is "no alternative". The only question is the one asked by Peter Pomerantsev: What if Russia "had been a pre-echo of what was to come in the thing once known as the West?" (Pomerantsev, 2019, p. 172).

\section{An ending in the absence of a conclusion}

Here's how it works. From 1918 to c. 1980, the U.S. as hegemon manifested and "enforced" the geoculture of liberal internationalism and Keynesianism, touted as the "right side of history" (humanitarian intervention et al.) but seen in hindsight as a temporary deviation from an underlying but repressed dynamic of unrestricted globalised primitive accumulation: the economic as criminogenic. It began to change between 1979-1980 (Thatcher-Regan) with the neo-liberal "revolution" within the core zone and the hegemon itself, which was not, in fact, revolutionary, but quintessentially reactionary, the return of that which had been "de-toured"-hence the frenzied economic rape of eastern Europe by western Europe

relative isolation from international banking and legal firms; all of this changed dramatically after Boris Yeltsin (Ibidem, p. 161 and 162); there is also a strong mimetic component, as the bureaucratic elites of poorer nations strive to emulate ("seize") the ostentatious consumption patterns of their "peers" in the core-zone; (Ibidem, pp. 163-173). 
(a.k.a. the E.U.) after 1989. The newly liberated emulators of "the thing once known as the West," precisely because they were new to the game and were hyper-mimetic, were very quickly able to get ahead of the curve: neo-liberalism is inherently anti-democratic and naturally favours some form of the neo-authoritarian political system, either technocratic or populist. Here is the uncanniness of it all: because they were able to internalise neo-authoritarianism within a neo-liberal global economy most wholly and rapidly, the eastern States of Europe were the best able to claim the hegemonic mantle of geo-culture. And the United States, as the hegemon and therefore the state most subject to foreign challenges, undertook international competition to its next logical level of intensity by voluntarily undergoing its own neoauthoritarian transformation in response to its eastern rivals: rightist neo-populism with the Republicans and technocratic elitism for the Democrats. ${ }^{27}$ What holds everything together in this entangled self-perpetuating chaos is the triangulation of mimetic desire: both the U.S. and the East, both neo-populists and the neo-technocrats, strive for the same object of their concurrent and convergent mimetic desire, the neo-authoritarian post-democratic neo-liberal order. The continuation of criminogenic asymmetries by other means.

Radical criminology really ties everything together.

\footnotetext{
${ }^{27}$ A note on the E.U.: although western Europe would appear to be bucking these trends, this is an illusion as I have shown Europe needs to do absolutely nothing because it has already attained the status of elitist technocratic paragon. It must never be forgotten that neo-liberalism was very much a German (and Austrian) invention.
}

\section{REFERENCES}

1. Arrighi Giovanni, Silver Beverley J. Introduction. In Chaos and Governance in the Modern World System (1-36). Minneapolis: University of Minnesota Press; 1999.

2. Babones Salvatore. The New Authoritarianism: Trump, Populism, and the Tyranny of Experts. Cambridge UK: Polity; 2018.

3. Badiou Alain. Trump. Cambridge, UK: Polity Press; 2019.

4. Brighi Elisabetta, Cerella Antonio. An Alternative Vision of Politics and Violence: Introducing Mimetic Theory in International Studies. Journal of International Political Theory. 2015;11(1):3-25.

5. Brown Wendy. Undoing the Demos: Neoliberalism's Stealth Revolution. New York: Zone Books; 2015.

6. Calasso Roberto. The Unnamable Present. Trans. Richard Dixon. New York: Farrar, Straus and Giroux; 2017.

7. Chatelet, Gilles. To Live and Think Like Pigs: The Incitement of Envy and Boredom in Market Democracies. Trans. Robin Mackay. London: Urbanomic Sequence; 2014.

8. Dornhoff G. William. Who Made American Foreign Policy, 1945-1963? In David Horowitz, (ed.), Corporations and the Cold War. New York: MRP; 1969.

9. Gilpin, Robert. War \& Change in World Politics. Cambridge UK: Cambridge University Press; 1981.

10. Grewe Wilhelm. The Epochs of International Law. New York: Walter de Gruyter; 2000.

11. Held David, McGrew Anthony, Goldblatt David, Perraton Jonathan. Global Transformations: Politics, Economics and Culture. Cambridge: Polity Press; 1999.

12. Ikenberry G. John, Kupchan Charles A. Socialisation and Hegemonic Power. International Organization. 1990;44(3):283-315.

13. Krastev Ivan, Holmes Stephen. The Light that Failed: A Reckoning. London: Allen Lane; 2019.

14. Kruse Kevin M., Zelizer Julian E. Fault Lines: A History of the United States Since 1974. New York: W.W. Norton \& Company; 2019.

15. Lacau Ernesto. On Populist Reason. London: Verso; 2005.

16. Legutko Ryszard. The Demon in Democracy: Totalitarian Temptations in Free Societies. Trans. Teresa Adelson. New York: Encounter Books; 2016.

17. Mazower Mark. Dark Continent: Europe's Twentieth Century. New York: Vintage Books; 1998.

18. Mbembe Achille. Necropolitics. Trans. Steven Corcoran. Durham, NC: Duke University Press; 2019.

19. Mehlman Jeffrey. Revolution and Repetition: Marx/Hugo/Balzac. Berkeley: University of California Press; 1977.

20. Memmi, Albert. The Colonizer and the Colonized. Beacon Press: Boston; 1991.

21. Milanovic Branko. Capitalism Alone: The Future of the System That Rules the World. Cambridge, MA: The Belknap Press; 2019. 
22. Osborne Peter, Roberts Tom. How Trump Thinks: His Tweets and the Birth of a New Political Language. London: Head of Zeus; 2017.

23. Ostrovsky Arkady. The Invention of Russia: The Rise of Putin and the Age of Fake News. New York: Penguin Books; 2017.

24. Passas Nikos. Corruption in the Procurement Process and Outsourcing Government Functions: Issues, Cases, Case Studies, Implications. Report Prepared for the Institute of Fraud Prevention. Report to Institute for Northeastern University. Boston; 2007.

25. Passas Nikos. Global Anomie, Dysnomie, and Economic Crime: Hidden Consequences of Neoliberalism and Globalization in Russia and Around the World. Social Justice. 2000;27(2):16-44.

26. Pomerantsev Peter. This is Not Propaganda: Adventures in the War Against Reality. New York: Public Affairs; 2019.

27. Pomerantsev Peter. Nothing is True and Everything Is Possible: The Surreal Heart of the New Russia. New York: Public Affairs; 2014.

28. Ruggiero Vincenzo, Welch Michael. Power Crime. Crime, Law and Social Change. 2009;51:297-301.

29. Slobodian Quinn. Globalists: The End of Empire and the Birth of Neoliberalism. Cambridge MA: Harvard University Press; 2018.

30. Schmitt Carl. The Concept of the Political. Trans. George Schwab. Chicago: University of Chicago Press; 1996.

31. Snyder Timothy. The Road to Unfreedom: Russia, Europe, America. London: Bodley Head; 2018.

32. Taubes Jacob. To Carl Schmitt: Letters and Reflections. Trans. Keith Tribe. New York: Columbia University Press; 2013.

33. Troy Jodok. Desire and Imitation in International Politics. East Lansing, MI: Michigan State University Press; 2021.

34. Virilio Paul, Richard Bertrand. The Administration of Fear. Trans. Ames Hodges. Los Angeles: Semiotext(e); 2012.

35. Wallerstein Immanuel. The Modern World-System II: Mercantilism and the Consolidation of the European WorldEconomy, 1600-1750. New York: Academic Press; 1980.

36. Wallerstein Immanuel. The Capitalist World-Economy. Cambridge UK: Cambridge University Press; 1979.

37. Walker Jonathan. James Ellroy as Historical Novelist. History Workshop Journal. 2002;53:181-204.

38. Wark McKenzie. Virtual Geography: Living with Global Media Events. Indianapolis: Indiana University Press; 1994.

39. Wilmes Andreas. Demystifying the Negative: Rene Girard's Critique of the 'Humanisation of Nothingness'. Forum Philosophicum. 2019;24(1):91-126.

40. Wilson Eric. Crimes Against Reality: Parapolitics, Simulation, and Power Crime. In Stephen Hall and Simon Winlow, (eds.), New Directions in Criminological Theory (292-316). London: Routledge; 2012.

41. Wilson Eric. Speed/Pure war/Power Crime: Paul Virilio on the Criminogenic Accident and the Virtual Disappearance of the Suicidal State. Crime, Law and Social Change. 2009;51(3-4):413-434.

42. Wilson Eric. The Savage Republic: De Indis of Hugo Grotius, Republicanism and Dutch Hegemony within the Early Modern World-System (c. 1600-1619). Leiden: Martinus Nijhoff Publishers; 2008.

43. Zuboff Shoshana. The Age of Surveillance Capitalism: The Fight for the Future at the New Frontier of Power. London: Profile Books; 2019.

\section{ABOUT THE AUTHOR}

Eric Wilson - Doctor of History, Doctor of Juridical Science (S.J.D.), Senior Lecturer, Monash University, Faculty of Law (Public International Law), Melbourne, Australia; an independent researcher, working in the field of Radical Criminology

eric.wilson@monash.edu

\section{OБ АВTOPE}

Эрик Уилсон - доктор исторических наук, доктор юридических наук, старший преподаватель, Университет Монаша, юридический факультет (международное публичное право), Мельбурн, Австралия; независимый исследователь, работающий в области радикальной криминологии eric.wilson@monash.edu 